\title{
CATTLE PLAGUE IN THE ANGLO-EGYPTIAN SUDAN.
}

By Lieut. A. S. HEAD, A.V.D.

THE following are some notes taken from my diary while working on cattle plague in the Sudan, giving the result of over I 3,000 cattle inoculated.

On the banks of the Nile cattle are solely used for turning waterwheels (sakhiers) for irrigating the cultivated land, no rain falling during the year, or at most only one or two showers.

Each native landowner cultivates from 2 to 6 acres of land along the river bank, four to eight cattle being used to turn one water-wheel,

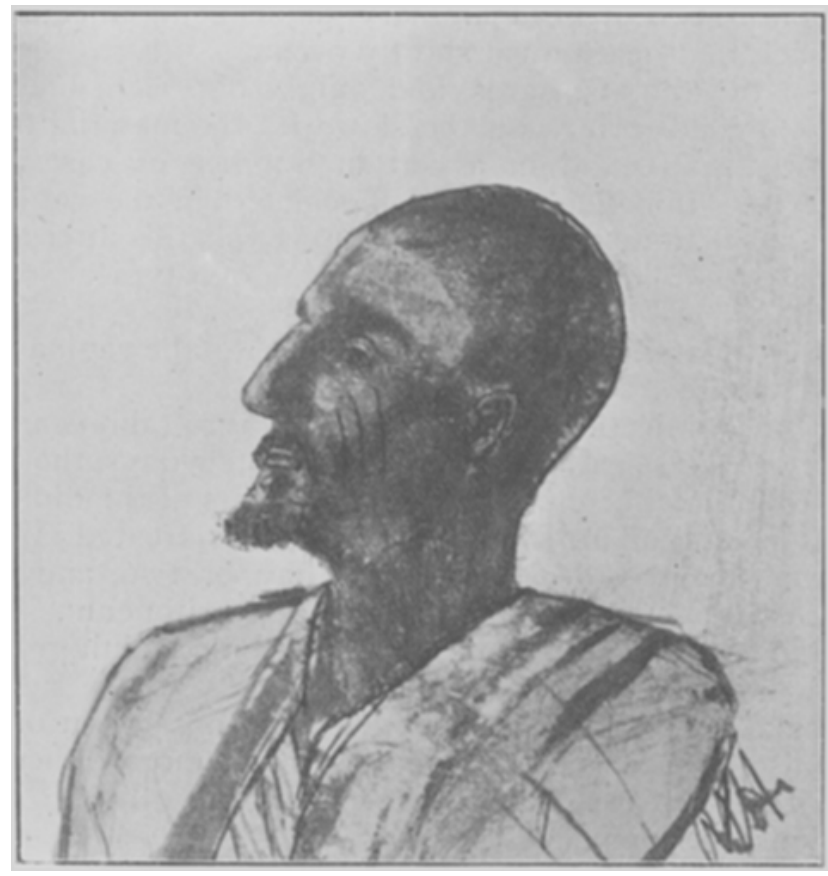

FIG. 1.

A native of the Nile.

working in pairs for two or three hours at a time. The land yields two crops yearly, which have to supply the owner with food for himself, his family, and oxen, there being no grazing except when the land is irrigated.

The water-wheels and strip of cultivated land extend in nearly one continuous line, along each bank of the river, from Wadi Halfa to Khartoum, a distance of over 700 miles, besides reaching far up the Blue Nile. Bordering this strip of cultivated land is sandy desert, reaching for miles east and west of the Nile, with only a few thorn bushes (kitr) and an occasional wadi (dried up water-course) in which sometimes a little dried up grass may be found.

Mixed races inhabit the river banks, the greatest number belonging probably to the Jarlines tribe. During the reigns of the Mahdi and 
Khalifa the river tribes were practically decimated, and even now the river banks are very thinly populated, and I should say not one third of the land cultivated before the Mahdi's time is now worked. The natives are mostly a peaceable lazy people, giving very little trouble.

In the interior, along the river Atbara, in the Kassala and Suakin provinces, bordering Abyssinia and Eretria, the population is made up of wandering tribes of Arabs, the chief among which are the Hadendoasr, the Shukria, and the Bisharin. They are a very independent primitive race of men, living entirely on their flocks and herds,

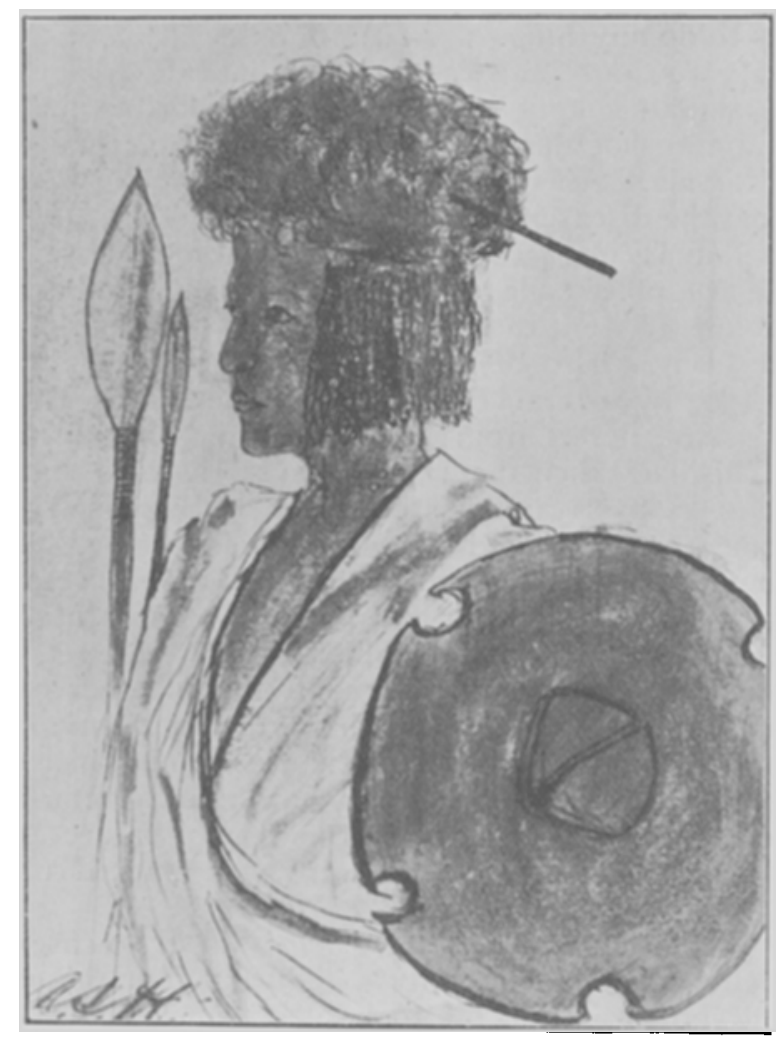

FIG. 2.

A Hadendoasr.

which consist of camels, sheep, goats, and cattle. They sow a small amount of native corn (dhura) yearly during the rainy months. They live chiefly on butter and milk taken from their goats, cows, and shecamels. They have no fixed abode, but move about with their flocks and herds to wherever the grass and water is plentiful. They water their cattle, goats, and sheep every two or three days, and their camels every fifth or sixth day.

The Arabs are of a light brown colour, with clean cut features, being quite a distinct race from the Sudanese, who are black, thicklipped, and have curly hair. When they need money they ply for hire with their camels as carriers from one town to another, each camel 
earning 6 to 8 piastres a day (about $1 / 2 \frac{1}{2}$ ), two men being in charge of ten camels.

The form of doctoring practised among themselves consists of "fire," "earth," or "water" ; everything else they think useless. Firing with a hot iron is their chief cure for every malady, either in man or animal; for instance, colic in man or animal is treated by burning a line across the abdomen, a sore is treated by burning a line round it and putting a red hot cinder on the sore.

During the cattle plague one often found then sitting down watching their herds die, and leaving the dead unburied, saying that the plague was sent by Rubonah (God) as he was angry with them, so it was useless to do anything.

In January I9O4 a report was received that cattle plague had broken out in the Italian colony of Eretria, which borders the Suakin and Kassala provinces of the Sudan; about the same time cattle began to die in Kassala. An Egyptian veterinary surgeon went there and reported that the disease was rinderpest.

On 15 th January 1904 I received word that four cattle had just died on the Nile at a place called Mutmir, about halfway between Berber and Khartoum. I went there at once and found that the four dead oxen came from a herd of eighty-two cattle bought at Kassala in December I 903 by several landowners on the Nile. They had been driven across the desert from Kassala to the Nile, a distance of 260 miles, and this had taken them thirty days. During that time there had been no sickness among them, the only casualty during the journey being one, destroyed for a broken leg. On their arrival at the Nile these cattle had been distributed to their several owners at various places between Mutmir and Berber, but at Mutmir they had not as yet been mixed with the sakhier cattle.

I at once went round and isolated from the other cattle all the animals that had come over in this herd, finding them all apparently fit with the exception of nineteen cattle at Mutmir which were sick.

The symptoms were: sunken eyes, coat staring, emaciation, very slight appetite, fæces hard, urine normal, temperature $102^{\circ}$ to $104^{\circ}$, pulse weak. In two cases there were well-marked ulcers in the mouth.

I destroyed four and made post-mortems, but in no case could I find anything definite, there being only a slight inflammation of the fourth stomach, but no ulceration. I took blood smears and searched for piroplasms and trypanosomes, but could find nothing.

Four days afterwards an ox that came from the Nile and had accidentally got mixed with this herd, developed rinderpest in a virulent form, with high temperature, running from the eyes, nose, and mouth, diarrhœa and dysentery, and ulceration in the mouth.

I at once slaughtered all the animals at Mutmir that belonged to this herd or had come in contact with them; in all, seventeen. These were in four small villages quite apart from one another; in three of these villages the disease stopped at once, and no new case occurred, but in the fourth the owners hid two oxen that had been in contact, which I found in some thick Kitr bushes a week afterwards, both with the plague, and so the disease spread to the sakhier cattle.

About the same time the disease broke out amongst the sakhier cattle in every village in which any of the cattle from this herd had 
gone, fifteen centres in all, reaching from Mutmir to Berber, a distance of over 100 miles; and this in spite of the fact that except at Mutmir and one other centre all the cattle from the herd of eightytwo that came from Kassala remained apparently healthy.

Inoculation was started at once, but the only serum then in the country was old, so inoculation with serum alone had to be carried on while experiments were made on susceptible cattle with virulent rinderpest blood and serum to standardise the strength of the serum. This was done with all serum before starting the simultaneous inoculation of virulent blood and serum.

The virulent blood used for inoculation was always subjected to a microscopical examination before using, to guard against the introduction and spread of other diseases, such as piroplasmosis and trypanosomiasis. Police were posted over all the infected centres, and no animal allowed to move.

The method adopted was to isolate all sick animals in the desert, ccrtain men being told off to attend them only, and living at the quarantine night and day. Then every infected sakhier and two sakhiers on each side of it were inoculated, the animals being allowed to continue their work until noticed sick. When the simultaneous inoculation of virulent blood and serum was used the infected sakhier and one on each side of it were inoculated with virulent blood and serum, and one sakhier on each side of these with serum alone.

Only in a very few places did the disease spread, but in nearly every case where serum inoculation was alone employed the sakhiers had later to be re-inoculated with virulent blood and serum, as in inoculation with serum alone, although it protects the animal for nearly three weeks, the disease invariably breaks out again after that interval. Of course, the oxen might be re-inoculated with serum every three weeks, if expense and time were no object, but even then there is the question how long this should be continued, as I have known a case occur in a place where the animals had been inoculated with serum only six weeks after the recovery of the last case. The place had been guarded by police all this time, and no movement of animals allowed.

I think in single inoculation the hardest thing is to say when the place is free from disease. For instance, an infected herd is inoculated with serum only, after which the disease stops for three weeks. At the end of this time an $\mathrm{Ox}$ A., being still partly protected by the serum, devolops cattle plague, but in such a mild form that it is not noticed, remains sick for two weeks, during which time he is capable of infecting other animals. At the end of these two weels an $O x$ B. develops the disease in a virulent form from $A$., the protection afforded to $\mathrm{Ox} B$. by the serum inoculation having worn off, and so the disease starts again as bad as before.

With the simultaneous inoculation with virulent blood and serum there is none of this. The work once done is done for good and all, and the place after two or three weeks is free.

The only thing one has to be careful of is to examine the virulent blood for other diseases before using it, and to use serum of a tested strength, making sure that neither too much nor too little is given. The disadvantage of the simultaneous inoculation is that by giving each animal the disease in a mild form each becomes capable of 
infecting others and so spreading the disease. I have not fourd this so; I could never trace the spread of the disease to inoculation. The inoculated animals were always kept away from others for two weeks.

Another disadvantage is that a few cattle take the disease in a too virulent form and die from the inoculation. The mortality from this is very small. In 7057 cases I inoculated with virulent blood and serum I only lost I 40 oxen, a little under 2 per cent.

On I4th April I904, the outbreak finished on the Nile, with the exception of a small village at Berber which was still quarantined.

The following is a summary of the inoculation done up to this date :-

Total cattle sick with rinderpest . . . . 357

Total deaths from rinderpest . . . . . . 208

Total recovered from rinderpest . . . . . . 149

Inoculated with serum only . . . . . $\quad .732$

Inoculated virulent blood and serum . . . . $\quad 329$

Total inoculated . $106 \mathrm{I}$

Deaths from inoculation 7 , or a fraction over 2 per cent.

On I6th April 1905 I left Khartoum for the infected area at Gedaref in the Kassala province, taking with me 6000 doses of serum, and a train of thirteen baggage camels. The distance is 260 miles. It was extremely hot, I $5^{\circ} \mathrm{F}$. in the shade during the day.

Travelling on camels in the Sudan during the summer months is rather a trying ordeal. Starting at 2 A.M. in the morning, one travels till 9 A.M., when it begins to get disagreeably hot ; one then spreads a blanket on the ground, and ties another up under a Kitr bush so as to make as much shade as possible, in which one lies sweltering in the heat, wondering if it will ever be cool again, till 4 P.M., when, although it is still uncomfortably hot, one starts again, travelling till IO P.M. ; then supper and bed, having travelled perhaps 30 miles.

Of course if one has no heavy baggage and can get trotting camels the distance can be done in half the time, as a good trotting camel goes five miles an hour, while a baggage camel only walks two and a half miles an hour.

Travelling in the wet season is next to impossible, although it has to be done, as a camel slips and flounders about in the mud, and it is often necessary to wait until the road has dried.

The rains are very heavy, wetting through everything one possesses, and sleeping in wet blankets is a common occurrence. Besides this, fever is very prevalent, and the natives are very susceptible to it and always ill.

For the first I 20 miles on my road to Gedaref water was plentiful, as the road lay along the bank of the Blue Nile, but after this water was scarce, and what there was was thick, slimy, and smelling. The last 82 miles was without water, the road lying over black cotton soil with only a very few small Kitr bushes. The drinking water for these three days had to be carried in skins, the greatest care being taken of it, as many a man loses his life from his water skins leaking or being pricked with thorns when off-loaded, and in these hot 
climates a man will hardly last twenty-four hours without water. The camels go the whole distance without water, and with only such food as they can pick up off the few stunted Kitr bushes that grow by the way.

I arrived at Gedaref on 30th April 1905.

Gedaref is an oasis city in the desert, the nearest water beyond it being the river Atbara, which is thirty-five miles away. It is one of the biggest agricultural towns in the Sudan, during the wet season miles and miles of country being sown with dhura (native corn). The surrounding country is covered with grass growing 12 to I 5 feet high in the wet season; the rest of the year it is dried up, but still affords good grazing for the herds.

I found that there were about 8000 cattle in Gedaref, all in herds of about 100 each. These cattle were all watered from the wells of Gedaref, and grazed near the town. Some of the oxen had been inoculated with serum alone, but the disease was still spreading, and the protection afforded by the serum dying off. I at once started inoculating with virulent blood and serum, remaining there three days. Leaving an Egyptian Veterinary officer to continue the inoculation, I went on to the Atbara river, where cattle plague was reported to be spreading.

The Atbara river rises in Abyssinia and flows through the Sudan, joining the Nile near Berber. During the wet season it comes down a raging torrent, a quarter of a mile wide, but during the dry season it only exists in pools. On each bank of the Atbara, reaching miles inland, the country during the wet season is covered by high grass, which dries up during the dry season but still affords good grazing for thousands of cattle, camels, goats, and sheep, which, owing to there being no water inland, must graze within thirty miles of the Atbara, so as to be able to come down to water. The Arabs water their cattle, sheep, and goats every two or three days, and their camels every sixth or seventh day when doing no work. Besides the flocks and herds that graze near the Atbara, there are thousands of gazelle, but I never found these take rinderpest. A few miles up the Settit river, which flows into the Atbara, are giraffe, elephant, buffalo, and kodu, but although cattle plague was in this part I never found or heard of any taking the disease, with the exception of kodu, some of which I found dead from cattle plague later on the north border of Eretria, near the Red Sea. The lions, hyena, and jackals, which are plentiful on the Atbara, were no doubt responsible for spreading the disease by carrying away parts of dead oxen which had died of cattle plague.

On my arrival at the Atbara river I found the disease extended from Sofi to Goz Regeb, a distance of i 80 miles, besides reaching a short way up the Settit river. I travelled to Kassala, and arranged for 200 police, with whom I returned, and policed every water hole in the infected part of the Atbara and Settit, making a list of all cattle that drank there, and, by ordering the owner of each herd that he was always to water at the same pool and on stated days, we were able to have all the 25,000 cattle inspected every three days, when drinking. A herd not coming to water on its right day, or at its right time, was reported, and camel police were sent out for it and the owner dealt with.

Quarantine stations were formed wherever the disease existed, all 
the sick being quarantined, and the infected herds and all others watering at the same pool inoculated with virulent blood and serum.

We found that one could inoculate 500 cattle a day, by doing two hours' work in the early morning before it got hot, and two in the evening. All the cattle for inoculation were put in yards walled by thick brush-wood of Kitr bush, which is very strong and thorny. One man was required to hold the animal's head and two to twist a rope round the hind legs, it being very rarely necessary to throw them.

The herd after inoculation was let out to graze, returning every ten days to be inspected, and the sick quarantined; but the great majority took the inoculation so mildly that, except for being a little off their food for one or two days, nothing was noticed wrong.

On 14th July cattle plague ceased to exist on the Atbara and Settit and Kassala. On Ioth September it finished at Gedaref, and although a new infected herd managed to cross from Eretria and start a new centre of infection later at Kassala, this was quickly stamped out by inoculation.

Up to that date our inoculations in Gedaref, Kassala, Atbara, and Settit were:-

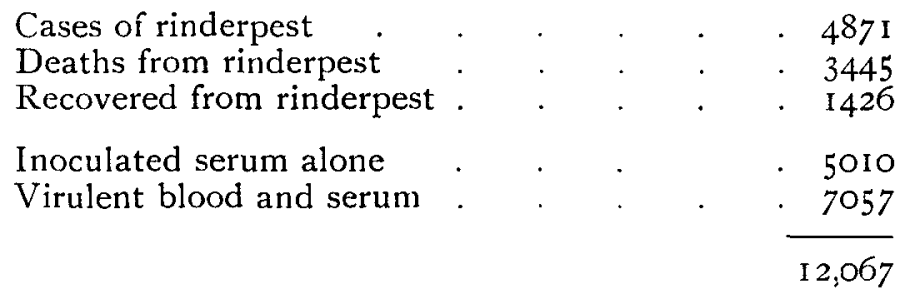

The summary of the cases of rinderpest and the inoculations from January I 905 to September 1905 is as follows :-

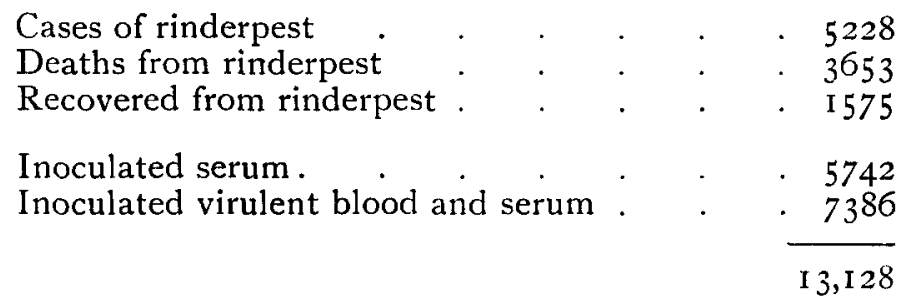

Deaths resulting from inoculation of virulent blood and serum, 2 per cent.

My experience during this time was that in dealing with large numbers of animals the only satisfactory inoculation was with virulent blood and serum. The inoculation with serum alone was unsatisfactory, owing to the impossibility of re-inoculating the cattle every three weeks.

The bile inoculation was not tried, it having been impossible to hope to collect sufficient of a good quality. The serum used came from the Government laboratories of Cairo and South Africa. Heat seemed to have no affect on the strength of the serum, as most of what we used had been carried for months on camels in the sun. 